\title{
The fight against climate change: the case of investment in renewables in Albania and Croatia
}

\begin{abstract}
Today, the fight against climate change also involves investment in the green economy and through sustainable development, a topic of particular interest to the United Nations which, with the 2030 Agenda, is aiming to reduce CO2 emissions and our impact on the environment, an agenda which has also been adopted thanks to the support of the European Union. This is demonstrated by the investment that Italy and the European Union are making in emerging and developing countries, as evidenced by funding in particular in the western Balkans which are not only having a positive impact on the environment but, in some cases, are creating new jobs and supporting the development of the skills base. We look here at particular examples of such funding in Albania and Croatia, the latter an EU member, the former an aspirant country, but both of which have chosen to pursue green energy both for intrinsic reasons of climate change and for reasons of diversifying the energy supply, but also as a route to accessing the funds which helps to procure advances in social and economic development.
\end{abstract}

Keywords: green economy, Albania, Croatia, C02, Agenda 2030

Introduction

The fight against climate change is now an investment in the future of the planet, with limiting the increase of the earth's temperature very much in view. It is, furthermore, also a form of investment and source of economic growth for many countries. The Balkans region is particularly sensitive to this issue, with countries such as Albania and Croatia showing that, with investment and green development projects, they are able to access and take advantage of many European-backed funds in the green energy sector.

\section{Combating climate change}

The issue of how to tackle climate change is back in vogue even after the muchdiscussed Paris Agreement, which proposed a clear cut in $\mathrm{CO}_{2}$ emissions and reduced human impact on the environment. The UN's 2030 agenda was adopted thanks to the support of the European Union, which has long been sensitive to environmental issues, while the European Commission's adoption of document COM(2018) 773 'A Clean Planet for all: A European long-term strategic vision for a prosperous, 
modern, competitive and climate neutral economy' ${ }^{1}$ has now led to the more recent 'reflection paper', intended to launch a debate on sustainable development, 'Towards a sustainable Europe by 2030'. This aims to define a green growth path for Europe by 2030, borrowing the UN's concept of Sustainable Development Goals, and outlines three scenarios for the achievement of these, based on the will of all member states, businesses and civil society for a greater commitment at community level to action. The target is an improvement in the life and well-being of citizens via a new sustainable economy allowing the EU to continue to thrive while, furthermore, through providing economic support to allow developing countries to catch-up economically and socially, would lead to a reduction of irregular migration.

The three scenarios are:

- An overarching EU SDG strategy to guide all actions by the EU and member states

In particular, this scenario aims to put EU policy and action at the heart of the UN's Agenda 2030, through a multilevel approach and in particular paying greater attention and consideration to relations between the European Union and third countries, with the aim of strengthening international action on sustainability

- Continued mainstreaming of the SDGs in all relevant EU policies by the Commission, but not enforcing member state action

This seeks to provides for a greater role for the European Commission, giving a Commissioner extensive responsibility as regards sustainability and facilitating greater development and collaboration within the Commission itself

- Putting enhanced focus on external action while consolidating current sustainability ambition at EU level

This shows a different approach to the problem, but it has in common the idea that Europe can take a lead role at global level, implying that the external action of the European Union would become a priority in the achievement of the strategic objective. What is envisaged is direct and more incisive action to support countries in the rest of the world, encouraging them to reach high standards in terms of compliance with environmental standards; as well as through negotiations and summits dedicated in particular to the promotion and the development of environmental standards. ${ }^{2}$

In this perspective of development and support for developing countries and countries outside the European Union, a key role is likely to be played by Italy which, in the period between 2000 and 2014, supported and implemented a variety of projects in the western Balkans aimed at 'modernising', as well as developing and raising awareness of environmental issues in the region. The projects and countries involved are as follows:

1 See Agostino Inguscio (2019) 'Cambiamento climatico: il futuro dell'Europa è nell'economia circolare' available at: https://www.ispionline.it/it/pubblicazione/cambiamento-climatico-il-fu turo-delleuropa-e-nelleconomia-circolare-22566.

2 See: https://ec.europa.eu/commission/publications/reflection-paper-towards-sustainable-europ e-2030_en. 
1. legislative support, international protocols and the acquis communautaire (Albania, Montenegro, Serbia)

2. air quality (Albania, Montenegro, Serbia)

3. Kyoto Protocol: Clean Development Mechanism and Joint Implementation (A1bania, Northern Macedonia, Montenegro, Serbia)

4. renewable energy and energy efficiency (Albania, Northern Macedonia, Montenegro, Serbia)

5. sustainable mobility (Montenegro)

6. sustainable construction (Northern Macedonia, Montenegro)

7. environmental education (Albania, Montenegro)

8. waste and reclamation (Serbia)

9. recovery of industrial sites (Northern Macedonia, Serbia)

10. sustainable construction (Northern Macedonia, Montenegro)

11. sustainable development, elaboration of a master plan and sustainable tourism (Northern Macedonia, Montenegro, Serbia).

According to the Ministry of the Environment, Italy has invested about $€ 30 \mathrm{~m}$ in these western Balkans projects, ${ }^{3}$ of which about 45 per cent has been invested in Montenegro, 36 per cent in Serbia, six per cent in Northern Macedonia and thirteen per cent in Albania, with a view to the potential further enlargement of the EU towards the western Balkans.

In percentage terms, most of the funds from the Ministry of the Environment invested in Albania have focused on climate change; similar with regard to Northern Macedonia in which around 40 per cent of the funds have been invested in climate and 31 per cent in renewable energy. As regards Montenegro, the focus has been on the sea and sustainable mobility, with 33 per cent and 26 per cent of the funds invested in these sectors respectively.

Concerning investments in Serbia, the Ministry's collaborative projects have been focused, and not by chance, on reclamation and environmental rehabilitation not least because of the conflict that, for years, has disrupted the country and in view of the use weapons that have not always been conventional.

Furthermore, investments in the field of environmental development have taken place through the European Bank for Reconstruction and Development (EBRD), whose investments in Serbia, for example, reach about 800 million euros. In 2015, the EBRD had the objective of financing about $€ 18$ bn of investment in green transition projects up to 2020. Thanks to access to some of this funding, Serbia has introduced a 'Belgrade bus renewal programme'; it has updated the water infrastructure of Belgrade; and it has financed a programme of credit lines for local banks aiming to contribute to projects for energy efficiency ${ }^{4}$ - so much so that projects for new lines of credit for efficiency in the property sector are now being studied.

3 For further details, see: https://www.minambiente.it/sites/default/files/archivio/allegati/svilup po_sostenibile/Balcani_26_09_2017.pdf.

4 Bachurova, Ana and Daniel Berg EBRD and the Green Economy Transition: A strategy for sustainable investments in Serbia available at: https://balkangreenenergynews.com/green-eco nomy-transition-in-serbia/. 
Montenegro has decided to invest in the green economy in the field of tourism, creating some 17,500 jobs, as can be seen from a recent UNEP/UNDP report, ${ }^{5}$ and has already included the concept of the green economy in its national strategy for sustainable development. The decision to invest in a sustainable economy is also due to around 13 per cent of total Montenegrin territory constituting a protected environment, producing a wealth of some 2.2 per cent of GDP, according to the UNDP.

\section{Albania and Croatia}

A focus on the gains that may come from developing and investing in renewable energy and energy efficiency can be had using the case studies of Albania and Croatia.

Albania has set itself the goal of producing 30 per cent of its electricity from renewable sources by 2020 and has thus been investing in the wind and photovoltaic sector, including via access to substantial funding from the European Bank for Reconstruction and Development. ${ }^{6}$

In November 2018, a conference was organised on social entrepreneurship and the green economy in Albania in order to encourage civil society and Albanian women to participate in programmes of development and support for social entrepreneurship, emphasising how, for the first time, social enterprises will be supported by the state and how these also aim at the greater integration of social groups considered vulnerable. The ultimate purpose of the conference was to create a network of partners who could support and develop a series of social enterprises as well as establish a favourable environment for the development of the green economy. ${ }^{7}$

The same year, the Albanian government announced the start of construction of a new solar park capable of generating about $100 \mathrm{MW}$ and with a total value of $€ 70 \mathrm{~m}$, to be located near the city of Vlorë and built by a consortium led by India Power Corporation. ${ }^{8}$ This highlights how countries on the Balkan peninsula are particularly sensitive to the development of new technologies related to the energy sector and, just as importantly, that they know how to seize the important opportunities for economic development that this sector can produce. Furthermore, competition over the development of renewable energies across the region is tight; in fact, a few months previously Montenegro had already contracted India Power and UAE-based Mining Resources FZE for the construction of a solar park that, at full capacity, would generate about 250MW of electricity.

5 Bassi, Andrea M (2006) Assessing the impact of green economy investments in Montenegro: a sectoral study focused on energy (transport and buildings) and tourism available at: https://ba lkangreenenergynews.com/wp-content/uploads/2016/10/Green-Economy-Montenegro-UNDP -Report.pdf. See also the Green Growth Knowledge Partnership's relevant knowledge platform at: http://www.greengrowthknowledge.org/country/montenegro.

6 'Albania: Entro il 2020, il 30\% delle Risorse Energetiche dalle Rinnovabili' Fare Impresa 18 May 2017, available at: http://esc.albaniaenergy.org/it/2017/05/20/esc_adriatic-2/albania-entr o-il-2020-il-30-delle-energia-dal-vento-e-sole-fare-impresa-18-maggio-2017/.

7 Advancing Social Entrepreneurship and Green Economy in Albania available at: http://www.u n.org.al/news/advancing-social-entrepreneurship-and-green-economy-albania.

8 Torrini, Sebastiano (2018) 'L'Albania completa la prima asta per le rinnovabili' available at: https://energiaoltre.it/rinnovabili-45/. 
To stimulate the development of renewable energies, the European Bank for Reconstruction and Development and the International Renewable Energy Agency have created ad hoc guidelines to facilitate countries implement projects that have as their goal the realisation of electrical power generated by renewable energy. ${ }^{9}$ As a demonstration of the country's ecological sensitivity, Albania in 2016 ranked third in Europe for the production of electricity from renewable and environmental sources.

Another Balkans country that has shown itself to be particularly sensitive to the issue of renewable energy is Croatia, which has set itself the goal of having 90 per cent of its energy requirements produced by renewable sources by $2050,{ }^{10}$ according to the laudable goal of the Croatian government.

One report produced at the beginning of 2017 showed that many Croatian power plants use renewable energy; in particular, wind and hydroelectric power. Croatia has invested around $€ 200 \mathrm{~m}$ in this sector, but is aiming for a rapid doubling of this figure in coming years, showing even greater sensitivity to the environment and clean energy but also a desire in geopolitical terms to become independent, from an energy point of view, from the states from which it imports oil.

The development of these types of renewable energies could have a negative impact in that such plants must be located in particular places, for example near water courses or in very sunny areas of the country that - at the same time - live off tourism. ${ }^{11}$ Consequently, Croatia is at something of a crossroads of a choice of whether to continue investing in the clean and renewable energy sector or continuing to focus on tourism; or, alternatively, find some way of combining the two.

\section{Conclusion}

These are just some of the ways in which the Balkans has invested Italian funds. What indeed is quite clear is the broad interest and awareness of the European Union when it comes to environmental matters, not to mention the impact that the fight against climate change, and investments on the green economy, have on countries that decide to invest in this sector. This not only involves economic development and environmental improvement but also sets in motion mechanisms that could drive further investment in the sector.

It can certainly be affirmed that, in the fight against climate change, investment in the green economy not only has repercussions for the health of the planet, in connection with which the problems linked to rising temperatures and the overheating associated with $\mathrm{CO} 2$ emissions have been known for a long time, but also with regard to the social and economic development of countries choosing to invest in green energy. For years, the United Nations has been adopting action plans that allow for the reduction of $\mathrm{CO}_{2}$ emissions, even if these have not been without a few difficul-

9 ibid.

10 Cheban, Viola 'La Croazia ha in programma di aumentare la propria quota di energie rinnovabili fino al 90\%' available at: http://www.ibcentre.tech/en/croatia-renewarle-energy1/.

11 'In Croazia Le Rinnovabili Vanno Bene, Ma Attenzione All'impatto Ambientale' available at: http://www.scienzaverde.it/energie-rinnovabili/situazione-croazia-attenzione-impatto-a mbiente/. 
ties. The European Union, which supports member states in investing in the green energy sector and in the development of sustainable technologies, has shown itself particularly keen to make progress on this issue.

In particular, the Balkans region has given a positive response to the demands for action made by the UN and the EU, both because Balkan states base a part of their economy on tourism and because they have shown themselves to be particularly aware of these issues, succeeding in accessing European development funds for the green economy. Within the region, Albania and Croatia have decided to focus attention on both hydroelectric and solar forms of renewable energy. Investment in this sector has also brought about an improvement in the social and employment sector, creating new jobs and new job opportunities, attracting foreign capital and also highly-specialised workers from other countries, in turn supporting the development of the skills base. This highlights how investment in renewable energies has many positive aspects both from an environmental and occupational point of view: opportunities that should also be seized by other states.

\section{References}

Adekola, Abel and Bruno S. Sergi (2016) Global Business Management: A CrossCultural Perspective New York: Routledge.

Bachurova, Ana and Daniel Berg EBRD and the Green Economy Transition: a strategy for sustainable investments in Serbia available at: https://balkangreenenergynews.com/green-economy-transition-in-serbia/.

Bassi, Andrea M (2006) Assessing the impact of green economy investments in Montenegro: a sectoral study focused on energy (transport and buildings) and tourism available at: https://balkangreenenergynews.com/wp-content/uploads/20 16/10/Green-Economy-Montenegro-UNDP-Report.pdf; http://www.greengrowthknowledge.org/country/montenegro.

Cheban, Viola 'La Croazia ha in programma di aumentare la propria quota di energie rinnovabili fino al 90\%' available at: http://www.ibcentre.tech/en/croatia-renewarle-energy $1 /$.

Galgóczi, Bela and Bruno S. Sergi (2012) 'Social and Economic Trends in Southeast Europe' SEER Journal for Labour and Social Affairs in Eastern Europe 15(1): 51-60.

Gradev, Grigor, Enisa Salimović and Bruno S. Sergi (2013) 'Developments of the Economies, Macroeconomic Indicators and Challenges in South-east European Countries' SEER Journal for Labour and Social Affairs in Eastern Europe 16(3): 251-277.

Inguscio, Agostino (2019) 'Cambiamento climatico: il futuro dell'Europa è nell'economia circolare' available at: https://www.ispionline.it/it/pubblicazione/c ambiamento-climatico-il-futuro-delleuropa-e-nelleconomia-circolare-22566.

Qerimi, Qerim and Bruno S. Sergi (2016) 'The Global Financial Crisis and the PostLisbon Prospects of Enlargement' South-East Europe Review for Labour and Social Affairs 12(4): 439-460. 
Sergi, Bruno S, Sanja Paunović and Rajko Kosanović (2018) 'Analysis of the main trends in wages, employment and poverty in south-eastern Europe' SEER Journal for Labour and Social Affairs 21(2): 201-218.

Sergi, Bruno S, William A. Bagatelas and Jana Kubicova (2012) Industries and Markets in Central and Eastern Europe Ashgate Publishing.

Sergi, Bruno S and Qerim Qerimi (2008) The Political Economy of Southeast Europe from 1990 to the Present: Challenges and Opportunities New York: Continuum.

Sergi, Bruno S and Qerim Qerimi (2007) 'Fighting Corruption and Organised Crime as a Means of Socio-economic Development in South-east Europe' South-East Europe Review for Labour and Social Affairs 10(2): 81-94.

Sergi, Bruno S and Qerim Qerimi (2006) 'Business Perspectives in Southeast Europe’ Transition Studies Review 13(3): 541-555.

Sergi, Bruno S (2005) 'The Balkans Jump on the Tax Rivalry Bandwagon' SouthEast Europe Review for Labour and Social Affairs 8(1): 7-18.

Sergi, Bruno S (2004) 'Understanding the "EU Factor": the Balkans Regions as Recipients of FDI and Industries' SEER-South-East Europe Review for Labour and Social Affairs 7(4): 7-20.

Sergi, Bruno S (2003) 'FDI and the Balkans: A Regional Investment Agency and Regional-Centred Economic Choices to Shape this Decade' South-East Europe Review for Labour and Social Affairs 6(1-2): 7-16.

Sergi, Bruno S (2003) Economic Dynamics in Transitional Economies: The Four-P Governments, EU Enlargement and the Bruxelles Consensus New York: Routledge.

Torrini, Sebastiano (2018) 'L'Albania completa la prima asta per le rinnovabili' available at: https://energiaoltre.it/rinnovabili-45/.

Ziolo, Magdalena and Bruno S. Sergi (Eds.) (2019) Financing Sustainable Development: Key Challenges and Prospects New York: Palgrave Macmillan.

Advancing Social Entrepreneurship and Green Economy in Albania available at: http://www.un.org.al/news/advancing-social-entrepreneurship-and-green-econom y-albania.

'Albania: Entro il 2020, il 30\% delle Risorse Energetiche dalle Rinnovabili' Fare Impresa 18 May 2017, available at: http://esc.albaniaenergy.org/it/2017/05/20/esc_a driatic-2/albania-entro-il-2020-il-30-delle-energia-dal-vento-e-sole-fare-impresa18-maggio-2017/.

'In Croazia Le Rinnovabili Vanno Bene, Ma Attenzione All'impatto Ambientale' available at: http://www.scienzaverde.it/energie-rinnovabili/situazione-croazia-att enzione-impatto-ambiente/. 
